\title{
ANALISIS INDRA PENGLIHATAN IKAN KERAPU MACAN (EPINEPHELUS FUSCOGUTTATUS) DAN HUBUNGANNYA DALAM MERESPONS UMPAN
}

\author{
(Visual Analysis of grouper (Epinephelus fuscoguttatus) and its relation to bait \\ response)
}

Oleh:

\author{
Mochammad Riyanto ${ }^{1 *}$, Ari Purbayanto ${ }^{1}$, Debby. S. S. Natsir ${ }^{2}$ \\ 1 Departemen Pemanfaatan Sumber Daya Perikanan, FPIK, IPB \\ 2 Alumni Departemen Pemanfaatan Sumber Daya Perikanan, FPIK, IPB \\ *Korespondensi: mh_ryn@yahoo.com
}

Diterima: 20 Januari 2011; Disetujui: 12 April 2011

\begin{abstract}
The visual organ in fish has an important role in ensuring its survival. Fish can respond to bait or food with its visual organ. The objectives of this research are to analyse the visual performance of grouper (cone cell morphology, the visual axis, and visual acuity) and to analyse the relation between visual senses with fish behavior response to the bait. This research was conducted in the laboratory by means of the determination of fish retina histology method and behavior of fish. The morphology retina of grouper consists of a single cone and double cone which form a mosaic structure, the visual axis was identified at upper-fore with the angle of $26.8^{\circ}$. The visual acuity of grouper was low in index values with ranged from 0.06 to 0.07 for fish with a total length of 200 to $300 \mathrm{~mm}$, the maximum sighting distance to the bait with the diameter of $20 \mathrm{~mm}$ size ranged from 3.93 to $4.74 \mathrm{~m}$, the bait with $25 \mathrm{~mm}$ diameter size range from 4.91 to 5.92 and bait with a diameter of $30 \mathrm{~mm}$ size ranged from 5.89 to $7.11 \mathrm{~m}$. The frequency of fish closed the bait distance of $30 \mathrm{~cm}$ was $45.83 \%, 25 \mathrm{~cm}$ was $33.33 \%$ and $20 \mathrm{~cm}$ was $20.83 \%$, respectively.
\end{abstract}

Key words: bait, Epinephelus fuscoguttatus, visual acuity

\begin{abstract}
ABSTRAK
Organ penglihatan ikan mempunyai peranan penting dalam menjamin kelangsungan hidupnya. Ikan dapat merespon umpan atau makanan dengan penglihatannya. Tujuan dari penelitian ini adalah untuk analisis penglihatan ikan kerapu; termasuk morfologi sel kon, sumbu penglihatan, dan ketajaman penglihatan dan menganalisis hubungan indera penglihatan dengan respons tingkah laku ikan kerapu macan terhadap umpan. Penelitian ini dilakukan dengan metode histologi retina ikan dan eksperimen tingkah laku ikan di laboratorium. Morfologi retina ikan kerapu terdiri dari satu kon dan sel kon ganda yang membentuk suatu struktur mosaik, sumbu penglihatan diidentifikasi upper-fore dengan sudut $26,8^{\circ}$, ketajaman penglihatan ikan kerapu ini rendah dengan nilai indeks berkisar antara 0,06-0,07 untuk ikan dengan total panjang 200-300 mm, jarak pandang maksimum untuk umpan dengan diameter $20 \mathrm{~mm}$ berkisar antara 3,93-4,74 $\mathrm{m}$, umpan dengan ukuran diameter $25 \mathrm{~mm}$ berkisar dari 4,91-5,92 dan umpan dengan diameter $30 \mathrm{~mm}$ berkisar antara 5,89-7,11 m. Frekuensi ikan mendekati umpan berturut-turut adalah $30 \mathrm{~cm}$ sebesar $45,83 \%$, $25 \mathrm{~cm}$ sebesar $33,33 \%$ dan $20 \mathrm{~cm}$ sebesar $20,83 \%$.
\end{abstract}

Kata kunci: umpan, Epinephelus fuscoguttatus, ketajaman penglihatan 


\section{PENDAHULUAN}

Ikan kerapu macan (Ephinephelus fuscoguttatus) merupakan salah satu jenis ikan ekonomis tinggi yang hidupnya di perairan terumbu karang, serta penyebarannya hampir di seluruh perairan Indonesia. Kerapu dapat ditemukan hampir diseluruh perairan Indonesia, mulai perairan barat Sumatera sampai perairan Maluku dan Papua. Sebagian besar produksi ikan kerapu di Indonesia berasal dari hasil tangkapan di alam menggunakan bahan peledak atau racun (potasium sianida) sehingga merusak lingkungan hidupnya dan dalam jangka panjang dapat menyebabkan kepunahan (Saparudin 2005). Oleh sebab itu dibutuhkan suatu cara penangkapan yang efektif, salah satu caranya adalah dengan mengetahui tingkah laku ikan itu sendiri.

Pengetahuan mengenai tingkah laku ikan memiliki peran penting dalam suatu operasi penangkapan ikan. Pengetahuan mengenai tingkah laku ikan ini merupakan dasar dan kunci bagi pengembangan metode dan teknik penangkapan ikan yang efisien dan efektif. Tingkah laku ikan tersebut diantaranya adalah tingkah laku ikan pada saat bermigrasi, berkelompok, tingkah laku agresif, beristirahat, bereproduksi, dan tingkah laku ikan pada saat mendapatkan makanannya (Moyle dan Cech 1988). Bagi kegiatan operasi penangkapan ikan tingkah laku ikan dalam mendapatkan makanannya merupakan hal yang sangat penting utuk diteliti, karena dengan adanya makanan merupakan daya tarik bagi ikan untuk datang.

Pada umumnya dalam upaya mendapatkan makanannya ikan menggunakan indera penglihatan dibantu oleh indera penciuman. Indera penglihatan pada ikan berperan sama pentingnya dengan indera penglihatan pada hewan vertebrata lainnya. Dengan menggunakan indera penglihatan ikan dapat merespons adanya makanan untuk menjamin keberlangsungan hidupnya. Indera penglihatan pada ikan akan memberikan respons apabila ikan tersebut tertarik terhadap suatu obyek dan selanjutnya akan mendekati obyek tersebut. Dengan menggunakan umpan dalam operasi penangkapan ikan, diharapkan dapat meningkatkan operasi penangkapan ikan yang lebih efektif dan efisien.

Umpan yang dipakaipun harus disesuaikan dengan kemampuan penglihatan ikan. Oleh sebab itu diperlukan suatu penelitian mengenai analisis indera penglihatan ikan kaitannya dengan respons terhadap umpan. Informasi yang didapat diharapkan nantinya dapat berguna bagi pengembangan metode penangkapan ikan agar lebih efektif dan efisien.
Tujuan penelitian ini adalah menganalisis indera penglihatan ikan kerapu macan, meliputi morfologi sel kon, sumbu penglihatan, dan ketajaman penglihatan dan menganalisis hubungan indera penglihatan dengan respons tingkah laku ikan kerapu macan terhadap umpan.

\section{METODE PENELITIAN}

Penelitian ini dilaksanakan dalam 3 tahap. Tahap pertama adalah pengambilan sampel mata ikan kerapu macan (Epinephelus fuscoguttatus) Januari 2008. Tahap kedua adalah melakukan analisis histologi sampel pada bulan Januari 2008 di Laboratorium Kesehatan Ikan, Departemen Budidaya Perairan, Fakultas Perikanan dan IImu Kelautan, Institut Pertanian Bogor. Tahap ketiga adalah observasi respons penglihatan ikan terhadap umpan dalam akuarium percobaan pada bulan Pebruari 2008 bertempat di Laboratorium Biologi dan Keanekaragaman Hayati Laut, Departemen IImu dan Teknologi Kelautan, Fakultas Perikanan dan IImu Kelautan, Institut Pertanian Bogor.

Ikan kerapu yang digunakan dalam penelitian ini adalah tujuh ekor ikan kerapu macan dengan ukuran panjang total 200-300 mm yang didapatkan dari keramba jaring apung (KJA) di Pulau Semak Daun, Kepulauan Seribu. Pengambilan sampel retina mata ikan dilakukan segera dan dimasukkan kedalam larutan bouin, sementara itu diameter lensa diukur sebesar 4,2-5,9 mm. Dengan menggunakan prosedur histologi, retina mata ikan disiapkan untuk pengamatan di bawah mikroskop melalui pemotongan secara tangensial dengan mikrotom ketebalan 0,4 $\mu \mathrm{m}$.

Pengambilan sampel retina mata ikan dilakukan dengan memotong mata ikan ke dalam 25 bagian. Masing-masing bagian tersebut dihitung jumlah sel kon untuk mengetahui bagian retina mata ikan dengan kepadatan sel kon terpadat. Dari bagian retina mata ikan dengan kepadatan sel kon terpadat ditarik garis lurus melewati pusat lensa mata ikan sehingga dapat ditentukan sumbu penglihatan (visual axis). Untuk menghitung ketajaman penglihatan (visual acuity) terlebih dahulu dihitung nilai sudut pembeda terkecil (minimum separable angle, MSA) dengan rumus (Tamura 1957):

$\propto_{\text {rad }}=\frac{1}{F} \times\left(\frac{2 \times 0,1 \times(1+0,25)}{\sqrt{n}}\right)$

dimana:

$\alpha_{\text {rad }}$ : sudut pembeda terkecil (menit)

$F$ : jarak fokus (berdasarkan formula Matthiensson's $F=2,55 \times r$ );

0,25 : nilai penyusunan spesimen mata akibat proses histologi; dan 

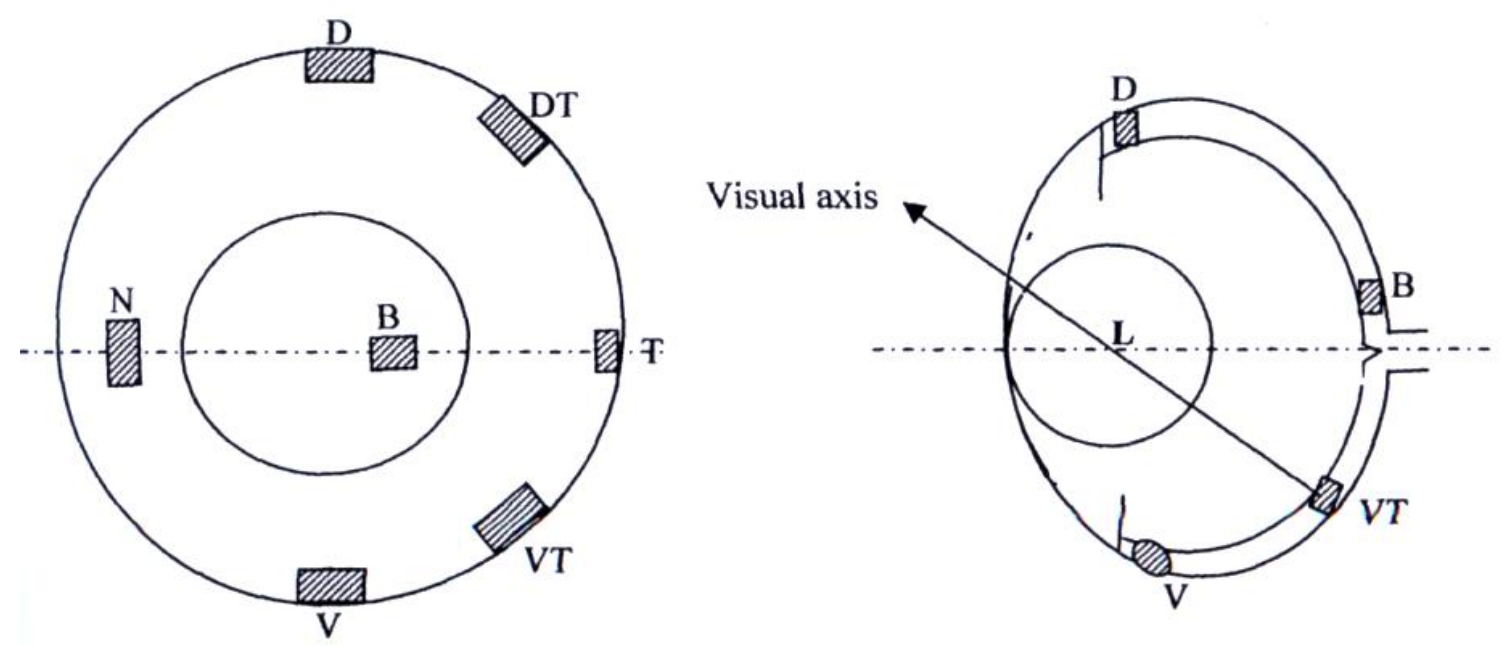

Keterangan:

$\begin{array}{llllllll}\text { T } & : \text { Temporal } & \text { VT } & \text { : Vento-temporal } & \mathrm{N} & : \text { Nasal } & \text { B } & \text { : Bottom } \\ \text { DT } & \text { : Dorso-temporal } & \text { D } & \text { : Dorsal } & \text { V } & \text { : Ventral } & \text { L } & \text { : Lensa }\end{array}$

Gambar 1 Skema pembagian retina dab penentuan sumbu penglihatan ikan (sumber: Tamura 1957).

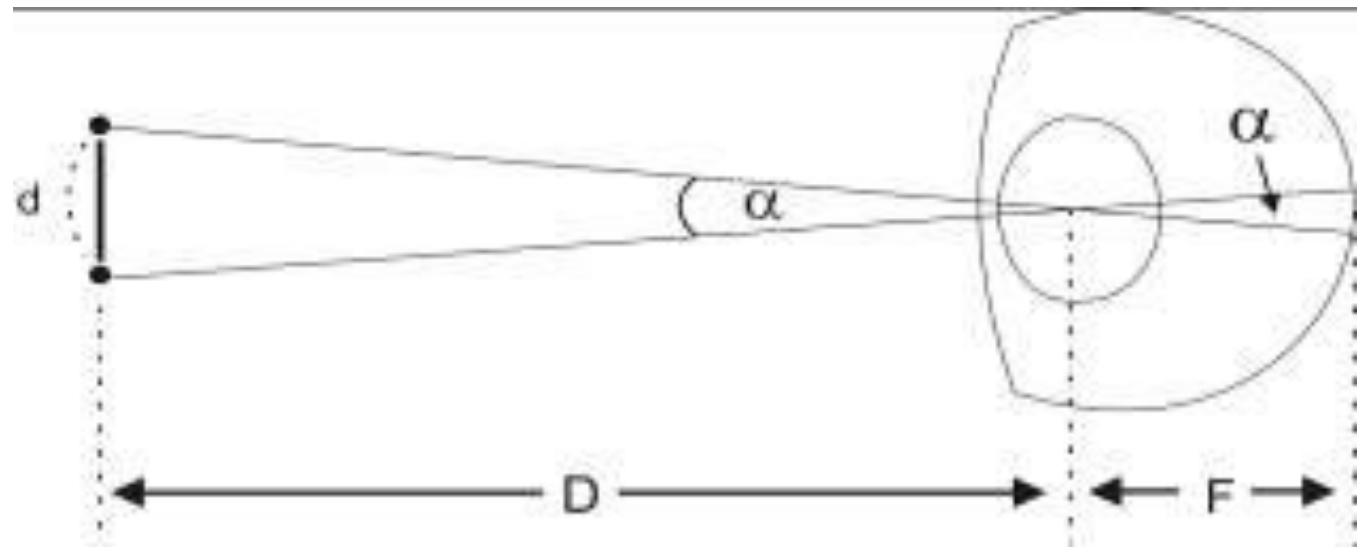

Keterangan : $\mathrm{D}=$ jarak pandang maksimum (meter)

$$
\begin{aligned}
& \mathrm{d}=\text { diameter obyek }(\mathrm{mm}) \\
& \alpha=\text { sudut pembeda terkecil (menit) } \\
& \mathrm{F}=\text { jarak titik fokus }(2,55 \times \mathrm{r})
\end{aligned}
$$

Gambar 2 Skema perhitungan jarak pandang maksimum.

$n \quad$ : kepadatan sel kon tertinggi per luasan $0,01 \mathrm{~mm}^{2}$ yang merupakan hasil pengamatan di bawah mikroskop

Setelah didapat nilai sudut pembeda terkecil (minimum separable angle, MSA), ketajaman penglihatan (visual acuity) dapat dihitung dengan rumus sebagai berikut (Shiobara et al. 1998):

$V a=\left(\alpha_{\text {rad }} \times \frac{180}{\pi} \times 60\right)^{-1}$

Sumbu penglihatan (visual axis) (Gambar 1) diperlukan untuk mengetahui kebiasaan ikan dalam melihat makanan atau obyek lain. Sumbu penglihatan diperoleh setelah nilai kepadatan sel kon tiap bagian dari retina mata ikan diketahui dengan cara menarik garis lurus dari bagian retina yang memiliki sel kon terpadat menuju titik pusat lensa mata (Tamura 1957).

Jarak pandang maksimum adalah kemampuan mata ikan untuk melihat obyek pada jarak terjauh berdasarkan nilai ketajaman penglihatan yang dimilikinya (Zhang dan Arimoto 1993). Perhitungan ini dilakukan dengan asumsi (Gambar 2): (1) Kondisi perairan dalam ke- 
adaan jernih (clear water); dan (2) Obyek yang menjadi sasaran penglihatan dalam bentuk titik (point acuity) yang diukur diameternya.

Adapun jarak pandang maksimum dapat dihitung dengan menggunakan rumus sebagai berikut ( Zhang dan Arimoto 1993):

$\tan (0,5) \propto=\frac{(0,5)}{D}$.

$D=\frac{(0,5) d}{\tan (0,5) \propto x}$.

dimana:

D : jarak pandang maksimum $(\mathrm{m})$

$d$ : diameter objek pandang $(\mathrm{mm})$

$\alpha$ : sudut pembeda terkecil (menit)

Pengamatan respons penglihatan terhadap perbedaan ukuran umpan

Pengamatan dilakukan pada pagi dan sore hari, umpan yang digunakan adalah ikan rucah dengan ukuran $20 \mathrm{~mm}, 25 \mathrm{~mm}$, dan 30 $\mathrm{mm}$. Ukuran tersebut disesuaikan dengan ukuran bukaan mulut ikan kerapu macan yang digunakan. Umpan tersebut dibungkus dengan plastik transparan. Tujuannya adalah agar pada saat perlakuan ikan hanya menggunakan indera penglihatannya dalam merespons umpan. Pengamatan dilakukan sebanyak 24 kali selama lebih kurang 30 hari terhadap 6 ekor ikan kerapu macan berukuran 230-290 mm.

Pengamatan dilakukan dalam bak perlakuan (Gambar 3), umpan digantung pada pipa dengan jarak 2 meter dari posisi start awal ikan dan 0,2 $\mathrm{m}$ dari dasar bak pengamatan. $\mathrm{Pe}$ masangan umpan pada jarak 2 meter dimaksudkan untuk melihat respons ikan mendekati umpan, yaitu frekuensi ikan yang mendekati umpan. Selama pengamatan aerator dibiarkan beroperasi agar kondisi bak sama seperti kondisi biasanya. Parameter yang diamati adalah ukuran umpan berapa yang akan dihampiri terlebih dahulu oleh ikan. Setelah pengamatan selesai dilakukan, umpan kemudian diangkat dan ikan diberi makan seperti biasa. Untuk melakukan pengamatan berikutnya ikan harus diaklimatisasi kembali selama dua hari, karena apabila pengamatan dilakukan secara terus menerus dapat menyebabkan ikan mengalami stres.

Respons penglihatan ikan terhadap perbedaan ukuran umpan dianalisis secara deskriptif. Analisis dilakukan dengan cara mengamati ukuran umpan mana dari ketiga umpan yang diberikan yang selanjutnya paling sering disentuh atau dihampiri oleh ikan. Untuk unit percobaan diasumsikan sebagai berikut: (1) Kondisi air dalam bak mendekati kondisi sebenarnya di alam; (2) Kondisi fisik ikan di labo- ratorium mewakili kondisi fisik ikan di perairan terbuka; (3) Panjang total tubuh dan bukaan mulut ikan dianggap sama; (4) Keadaan ikan dianggap sama untuk setiap perlakuan; dan (5) Kondisi umpan dianggap sama untuk setiap perlakuan.

Persentase frekuensi ikan menghampiri umpan dapat dihitung dengan rumus sebagai berikut:

$l u=\frac{f u}{\sum n} \times 100$. )

dimana:

$l u=$ persentase frekuensi ikan menghampiri ikan

$f u=$ frekuensi ikan menghampiri umpan

$\Sigma n=$ jumlah pengamatan

\section{HASIL DAN PEMBAHASAN}

\section{Morfologi retina mata ikan kerapu macan (Epinephelus fuscoguttatus)}

Dilihat dari hasil histologi mata ikan kerapu macan (Epinephelus fuscoguttatus) diketahui bahwa retina mata ikan ini tersusun dari sel kon tunggal dan sel kon ganda yang membentuk susunan mosaik (satu sel kon tunggal dikelilingi empat buah sel kon ganda) (Gambar 4), dengan rasio antara sel kon ganda terhadap sel kon tunggal adalah 2,1:1. Nilai rasio perbandingan ini disebabkan adanya sel kon ganda yang sama juga merupakan susunan mosaik dari yang lainya (satu sel kon ganda dapat mengelilingi lebih dari satu sel kon tunggal). Hal ini sesuai dengan yang dikatakan Sale (1991) bahwa pada ikan karang memiliki sel kon berpola mosaik. Pada umumnya ikan yang memiliki sel kon dalam bentuk mosaik adalah jenis ikan yang aktif memburu mangsa (predator fish) (Zhang dan Arimoto 1993).

\section{Ketajaman penglihatan ikan kerapu macan}

Ketajaman penglihatan pada ikan tergantung pada 2 faktor, yaitu diameter lensa mata dan kepadatan sel kon. Ukuran diameter lensa akan meningkat sejalan dengan bertam-bahnya ukuran tubuh ikan. Ikan dengan ukuran panjang total $200 \mathrm{~mm}$ memiliki diameter lensa sebesar 4,2 $\mathrm{mm}$ dan untuk panjang total $300 \mathrm{~mm}$ diameter lensanya sebesar 5,9 mm. Gambar 5 menjelaskan bahwa pertambahan panjang tubuh sebesar satu satuan maka ukuran diameter lensa akan bertambah sebesar 0,02 satuan. Nilai korelasi yang diperoleh sebesar 0,93, yang berarti bahwa panjang total dengan dia- 
meter lensa memiliki hubungan yang sangat erat. Hubungan linier antara panjang total tubuh

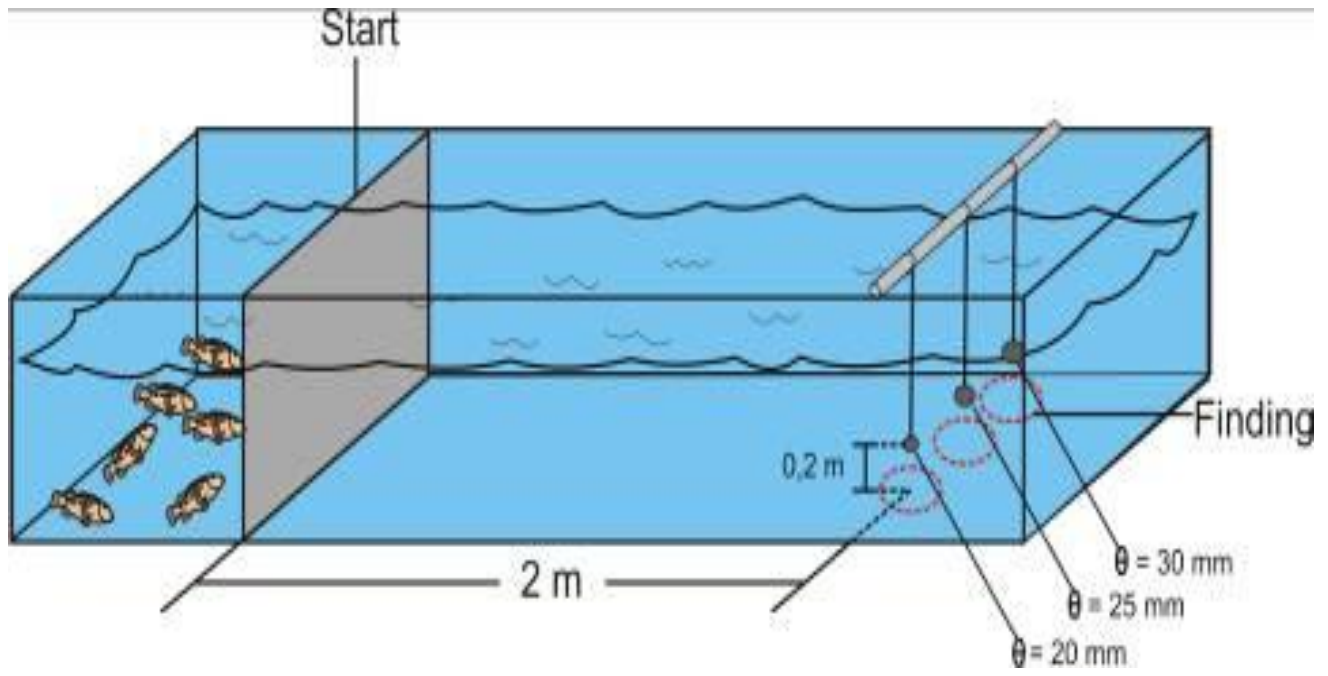

Gambar 3 Bak perlakuan pada observasi tingkah laku ikan kerapu macan.
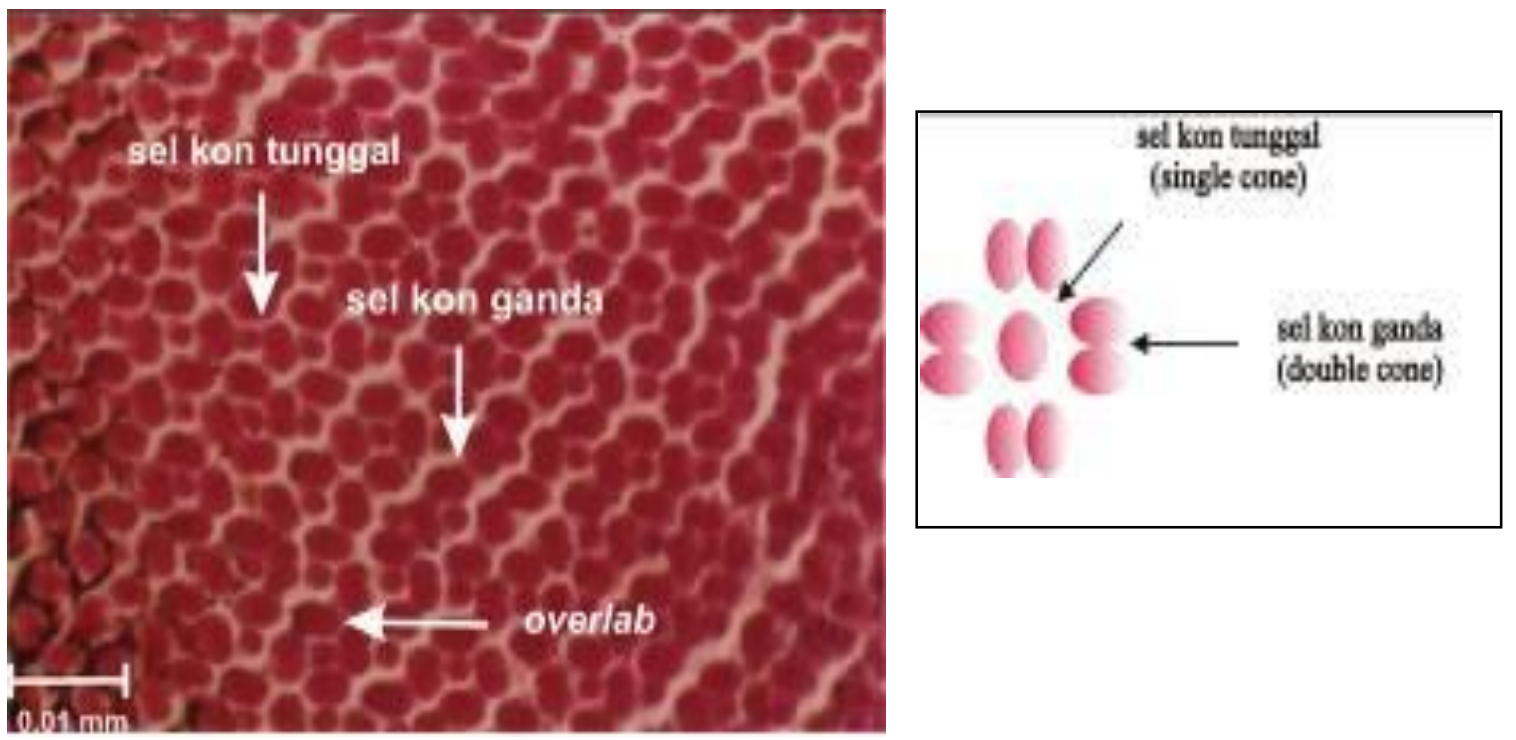

Gambar 4 Bentuk sel kon tunggal (single cone) dan sel kon ganda (double cone) ikan kerapu macan.

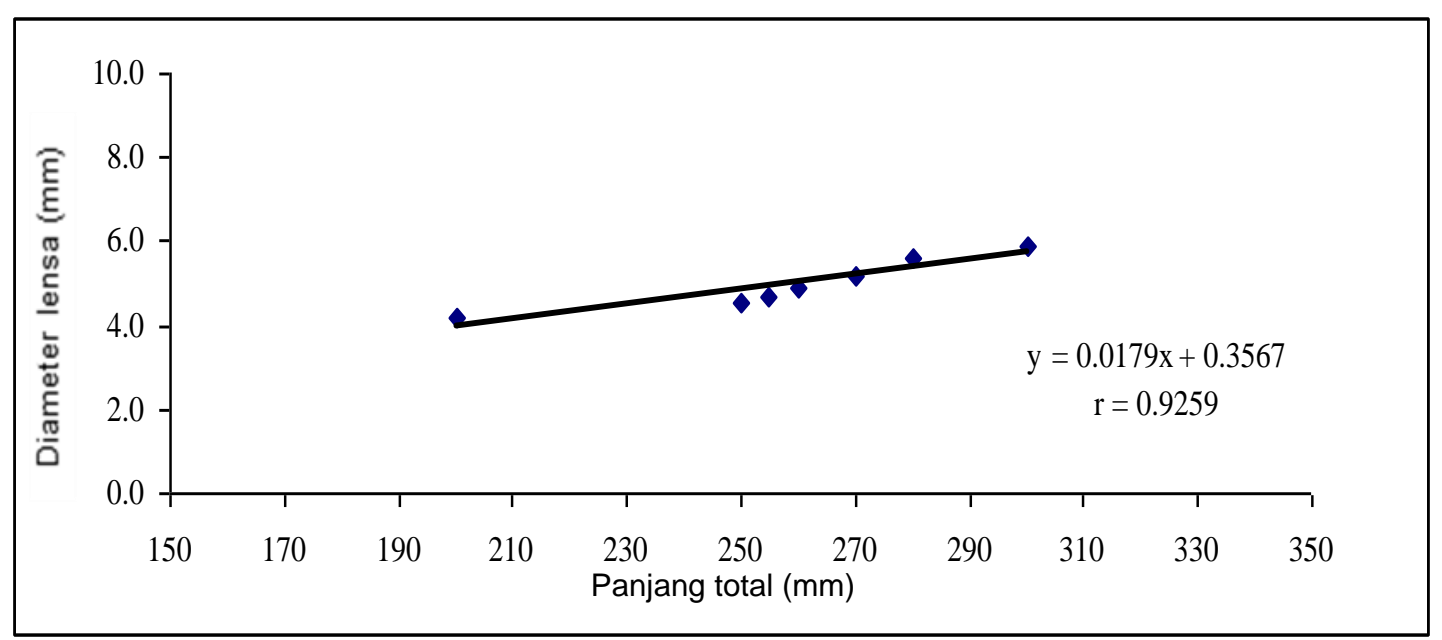

Gambar 5 Hubungan antara panjang total dan diameter lensa ikan kerapu macan. 


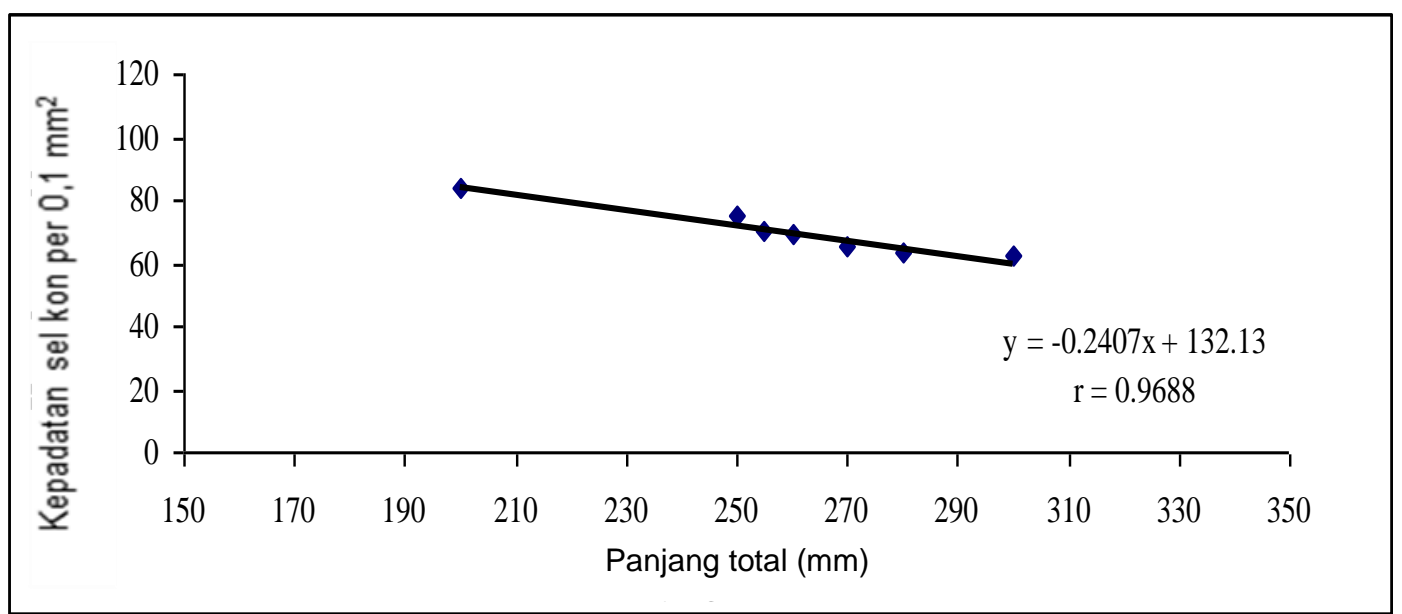

Gambar 6 Hubungan antara panjang total dan kepadatan sel kon ikan kerapu macan.

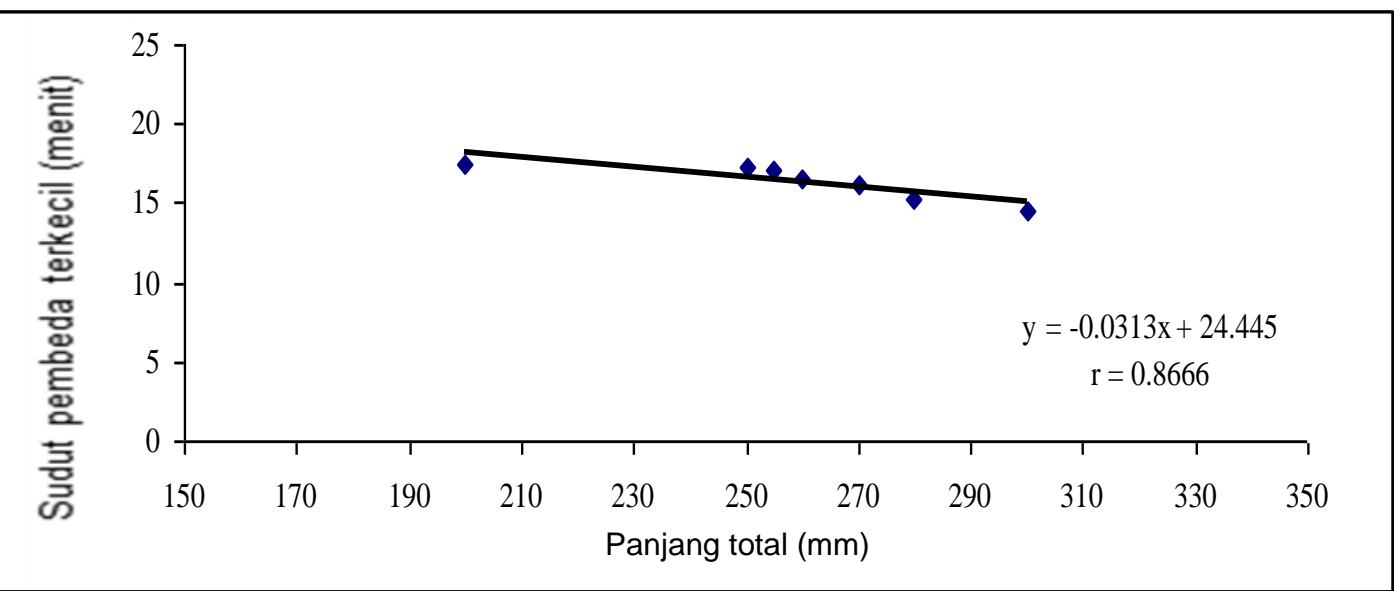

Gambar 7 Hubungan antara panjang total dengan sudut pembeda terkecil ikan kerapu macan.

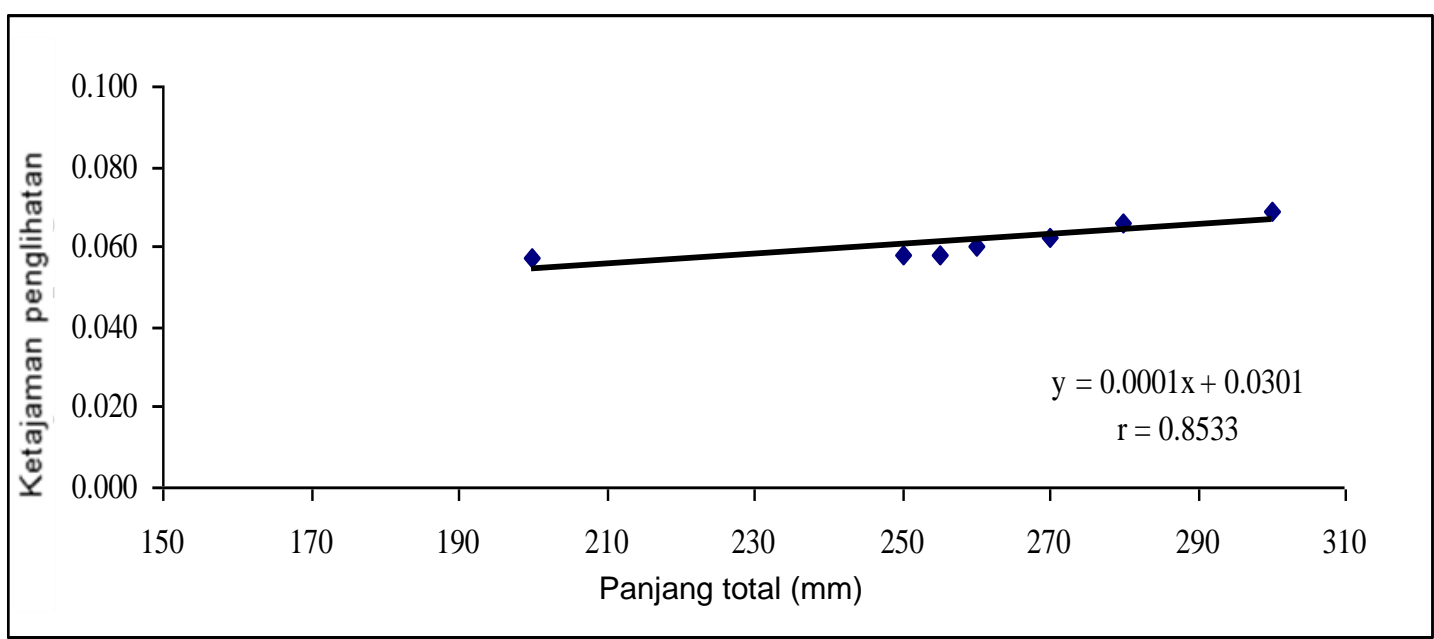

Gambar 8 Hubungan antara panjang total dengan ketajaman penglihatan ikan kerapu macan.

dan diameter lensa mata mata ikan kerapu macan dapat dilihat pada Gambar 5.

Hubungan antara panjang total dan kepadatan sel kon adalah berbanding terbalik, dimana semakin besar ukuran panjang tubuh ikan maka kepadatan sel konnya akan semakin menurun. Untuk ukuran panjang total $200 \mathrm{~mm}$ memiliki kepadatan sel kon sebanyak $84 \mathrm{sel} /$ $0,01 \mathrm{~mm}^{2}$, sedangkan untuk ukuran panjang total $300 \mathrm{~mm}$ memiliki kepadatan sel kon sebanyak $62 \mathrm{sel} / 0,01 \mathrm{~mm}^{2}$ (Gambar 6). Kedua hal ini sesuai dengan apa yang disebutkan oleh Purbayanto et al. (2001) bahwa diameter lensa 
mata ikan akan meningkat dengan bertambahnya ukuran tubuh, sementara itu kepadatan sel kon cenderung menurun dengan meningkatnya pertambahan penjang tubuh ikan.

Gambar 6 menjelaskan bahwa setiap pertambahan panjang total sebesar satu satuan maka akan mengurangi kepadatan sel kon sebesar 0,24 satuan. Nilai korelasi regresi diperoleh sebesar 0,97 , yang berarti bahwa pertambahan panjang total memiliki hubungan yang sangat erat dengan kepadatan sel kon.

Nilai sudut pembeda terkecil untuk ikan dengan ukuran panjang total $200 \mathrm{~mm}$ adalah sebesar 17,52 menit, dan untuk ukuran panjang total $300 \mathrm{~mm}$ adalah sebesar 14,52 menit (Gambar 7). Dapat disimpulkan bahwa semakin besar ukuran panjang total maka nilai sudut pembeda terkecil semakin berkurang, kesimpulan ini berarti ketajaman penglihatan akan semakin meningkat dengan berkurangnya nilai sudut pembeda terkecil. Hal ini sesuai dengan yang dilaporkan oleh $\mathrm{He}$ (1989) bahwa pertambahan panjang tubuh ikan menyebabkan semakin tingginya ketajaman penglihatan dengan nilai sudut pembeda terkecil yang semakin kecil. Dari grafik Gambar 7 dapat diketahui nilai korelasi sebesar 0,87 yang berarti bahwa hubungan antara panjang total dengan sudut pembeda terkecil sangat erat. Berdasarkan regresi tersebut setiap pertambahan panjang total ikan satu satuan maka akan menurunkan nilai sudut pembeda terkecil sebesar 0,03 satuan.

Ikan dengan ukuran panjang total sebesar $200 \mathrm{~mm}$ memiliki nilai ketajaman penglihatan sebesar 0,06 dan untuk ukuran panjang total $300 \mathrm{~mm}$ adalah sebesar 0,07 (Gambar 8). Hal ini sesuai dengan yang dikatakan He (1989) bahwa pertambahan panjang tubuh ikan menyebabkan semakin tingginya ketajaman penglihatan dengan nilai sudut pembeda terkecil yang semakin kecil.

Nilai korelasi regresi yang diperoleh sebesar 0,85, yang berarti bahwa panjang total dan ketajaman penglihatan memiliki hubungan yang sangat erat dan saling mempengaruhi. Berdasarkan regresi tersebut, pertambahan panjang total ikan satu satuan akan meningkatkan ketajaman penglihatan sebesar 0,0001 satuan.

\section{Sumbu penglihatan (visual axis)}

Dari hasil analisis histologi, diperoleh kesimpulan bahwa ikan kerapu macan memiliki sumbu penglihatan ke arah depan-naik (upperfore) dengan sudut sekitar $26,8^{\circ}$. Hal ini dapat dilihat dari kepadatan sel kon tertinggi pada bagian ventro temporal (Gambar 9), yaitu dengan menarik garis lurus melalui pusat lensa mata ikan sehingga diperoleh arah sumbu penglihatan ikan kerapu macan. Selain itu telah dibuktikan pula melalui pengamatan di laboratorium bahwa sumbu penglihatan ikan kerapu macan adalah benar menghadap ke arah depan-naik (upper-fore). Kepadatan sel kon ikan kerapu macan yang terpusat pada bagian ventro temporal ini sesuai dengan yang dikemukakan oleh Tamura (1957) dan Blaxter 1980 bahwa jenis ikan yang memperoleh makanannya dengan terlebih dahulu memburu mangsanya, maka pada umumnya mereka mempunyai pengkonsentrasian sel kon pada bagian temporal ataupun ventro-temporal retina matanya. Kepadatan sel kon pada bagian ventro-temporal retina mata ikan kerapu macan ini sama halnya dengan kepadatan sel kon pada ikan kakap merah (Lutjanus malabaricus) (Geonita 2004) dan ikan gulamah (Argyrosomus emoyensisi) (Agustini, 2005) yang juga merupakan jenis ikan pemangsa (predator).

Dari sumbu penglihatan ikan kerapu macan maka dapat diketahui cara makan ikan tersebut. Ikan kerapu macan memiliki kebiasaan menyergap mangsanya dengan tiba-tiba ke arah depan dan kearah depan-naik, hal ini sesuai dengan hasil analisis sumbu penglihatan bahwa ikan kerapu macan memilki sumbu penglihatan depan naik (upper-fore). Menurut Gufran dan Kordi (2005), bahwa ikan kerapu yang dipelihara pada kolam pemeliharaan akan memiliki kebiasaan menyergap satu persatu umpan yang diberikan sebelum pakan tersebut sampai ke dasar. Kerapu dalam keadaan lapar di keramba terlihat siaga dan selalu menghadap ke permukaan air dengan mata bergerakgerak siap memangsa pakan. Kerapu tidak pernah mau mengambil atau mencaplok pakan yang diberikan apabila sudah jatuh ke dasar, meskipun kerapu dalam keadaan lapar.

\section{Jarak pandang maksimum (maximum sighting distance)}

Jarak pandang maksimum ikan kerapu macan dengan kisaran panjang total 200-300 $\mathrm{mm}$ relatif sama pada saat melihat obyek. Nilai jarak pandang maksimum ini dihitung berdasarkan nilai sudut pembeda terkecil. Obyek penglihatan yang digunakan adalah umpan dengan ukuran $20 \mathrm{~mm}, 25 \mathrm{~mm}$, dan $30 \mathrm{~mm}$ (Gambar 10).

Ikan kerapu macan dengan ukuran panjang total 200-300 mm dapat melihat obyek berukuran $20 \mathrm{~mm}$ dengan nilai jarak pandang maksimum berkisar 3,93-4,74 m, untuk obyek berukuran $25 \mathrm{~mm}$ jarak pandang maksimum berkisar 4,91-5,92 m, dan untuk obyek berukuran 30 $\mathrm{mm}$ jarak pandang maksimum berkisar 5,89$7,11 \mathrm{~m}$. 


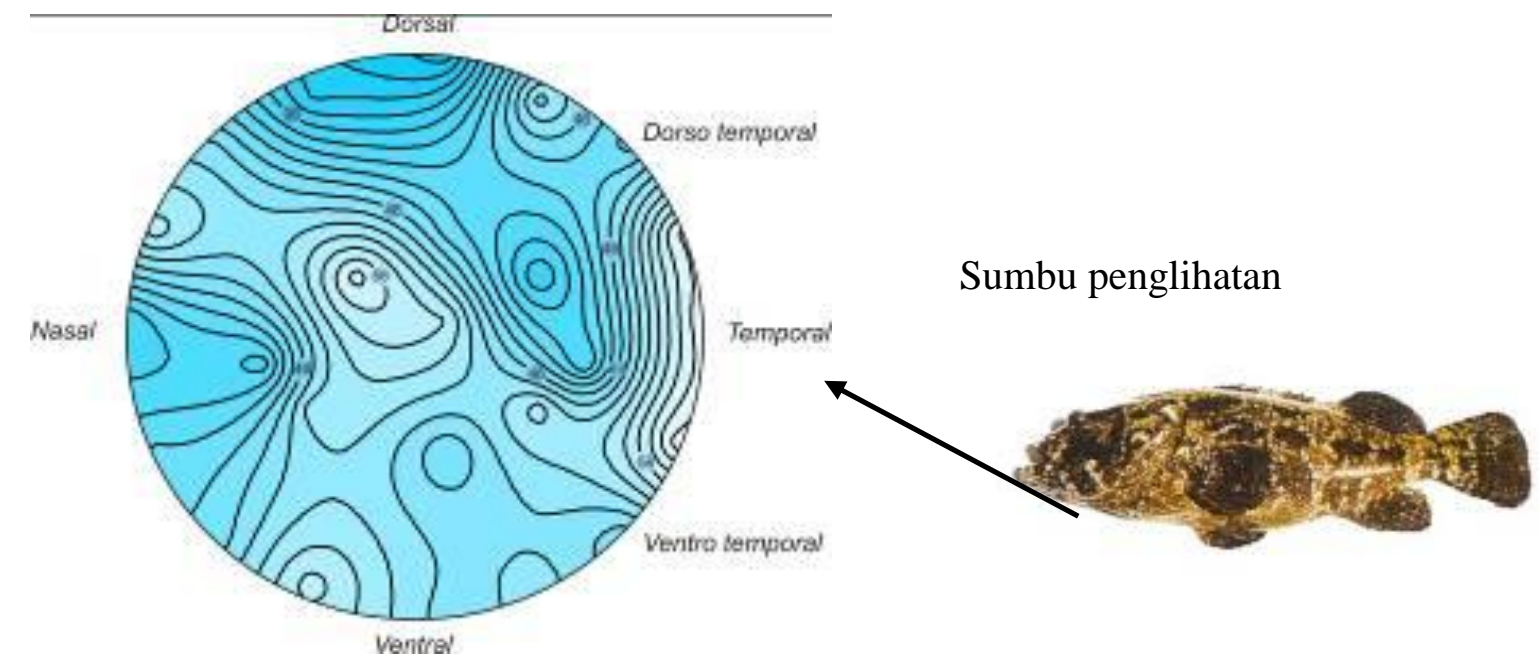

Gambar 9 Peta kontur kepadatan sel kon retina mata ikan kerapu macan dan sumbu penglihatannya.

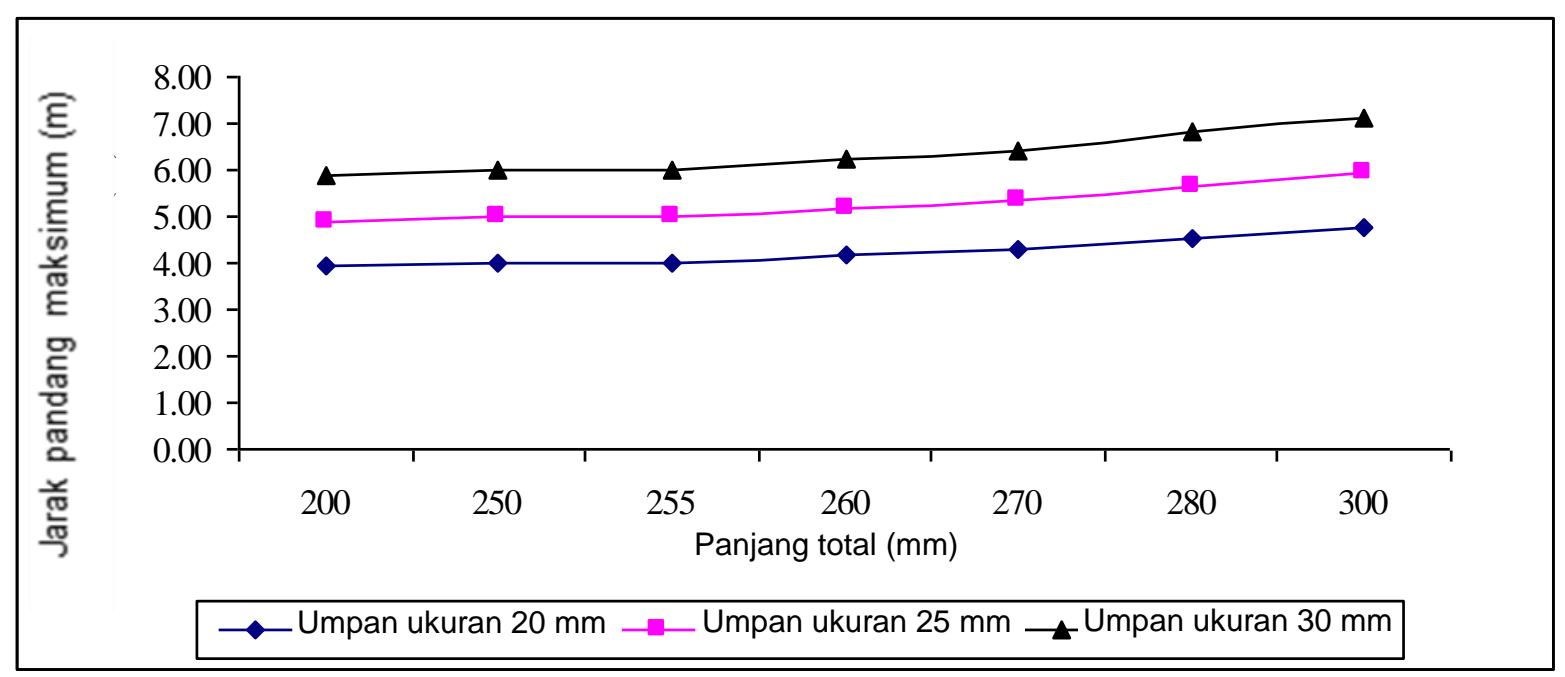

Gambar 10 Hubungan antara panjang total ikan kerapu macan dengan jarak pandang maksimum.

Nilai jarak pandang ikan kerapu macan untuk ukuran panjang total $200-300 \mathrm{~mm}$ adalah relatif sama. Hal ini disebabkan oleh nilai ketajaman penglihatan dan perbedaan panjang total ikan sampel yang diteliti relatif rendah. Nilai jarak pandang maksimum ikan kerapu macan ini tergolong rendah, mengingat ikan ini hidup di habitat terumbu karang yang cenderung pasif bergerak dan menunggu datangnya mangsa. Pertambahan panjang ikan kerapu menyebabkan pertambahan jarak pandang maksimum, Pertambahan ukuran objek umpan juga menyebabkan peningkatan jarak pandang maksimum ikan kerapu.

\section{Respons penglihatan terhadap perbedaan ukuran umpan}

Berdasarkan observasi di laboratorium maka dapat disimpulkan bahwa ukuran umpan yang lebih besar $(30 \mathrm{~mm})$ memiliki frekuensi di- hampiri ikan lebih banyak dibandingkan ukuran umpan yang lebih kecil ( 20 dan $25 \mathrm{~mm}$ ), hal ini karena ukuran umpan yang lebih besar akan mudah terlihat dibandingkan dengan ukuran umpan yang lebih kecil. Ukuran umpan sebesar $20 \mathrm{~mm}$ memiliki nilai frekuensi dihampiri ikan sebesar 20,83\%, umpan ukuran $25 \mathrm{~mm}$ sebesar 33,33\%, dan umpan ukuran $30 \mathrm{~mm}$ memiliki nilai frekuensi sebesar $45,83 \%$. (Gambar 11).

Ikan dapat merespons adanya umpan dengan baik ada jarak ikan terhadap umpan sejauh $2 \mathrm{~m}$ dengan ukuran umpan sebesar 20$30 \mathrm{~mm}$, Hal ini disebabkan karena ikan kerapu macan memiliki nilai jarak pandang maksimum (maximum sighting distance) berkisar 3,93-7,11 $\mathrm{m}$ untuk ukuran umpan sebesar 20-30 mm, sehingga observasi di laboratorium yang hanya dengan jarak sejauh $2 \mathrm{~m}$ saja tentu akan direspons ikan dengan baik (Gambar 12). 


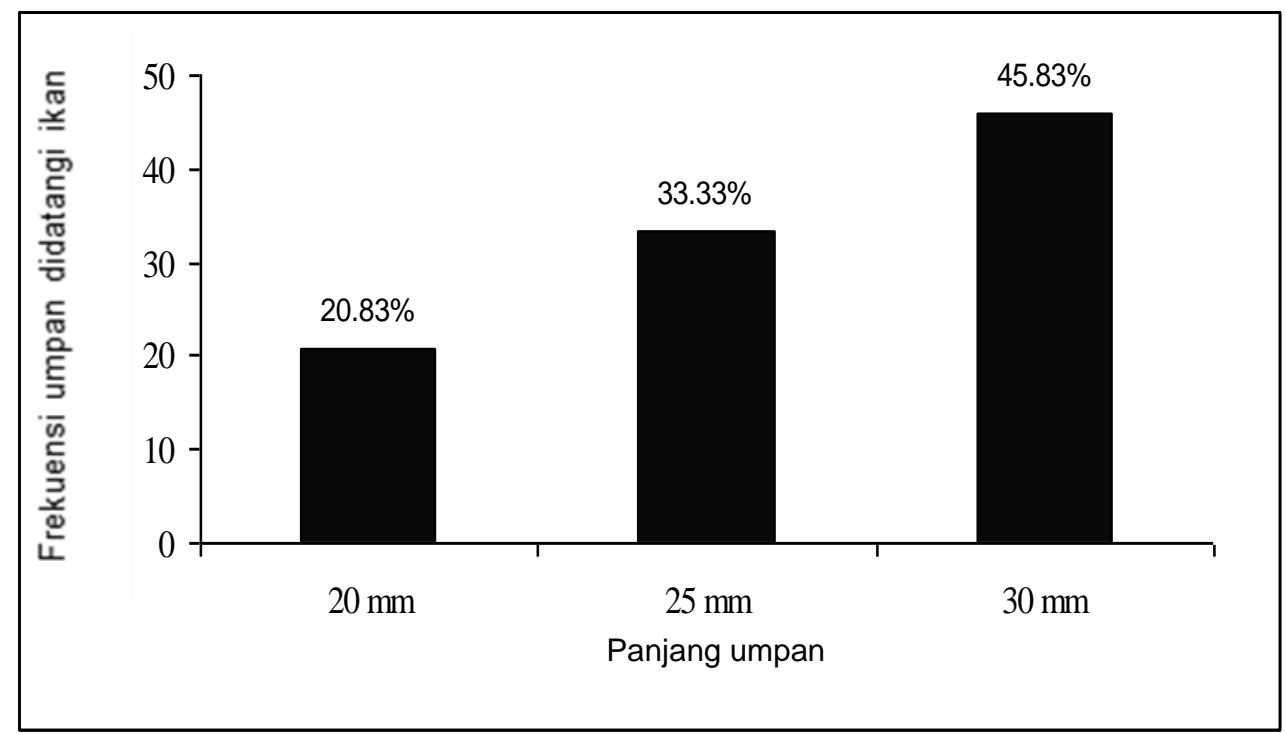

Gambar 11 Hubungan antara ukuran umpan dengan frekuensi umpan didatangi ikan.

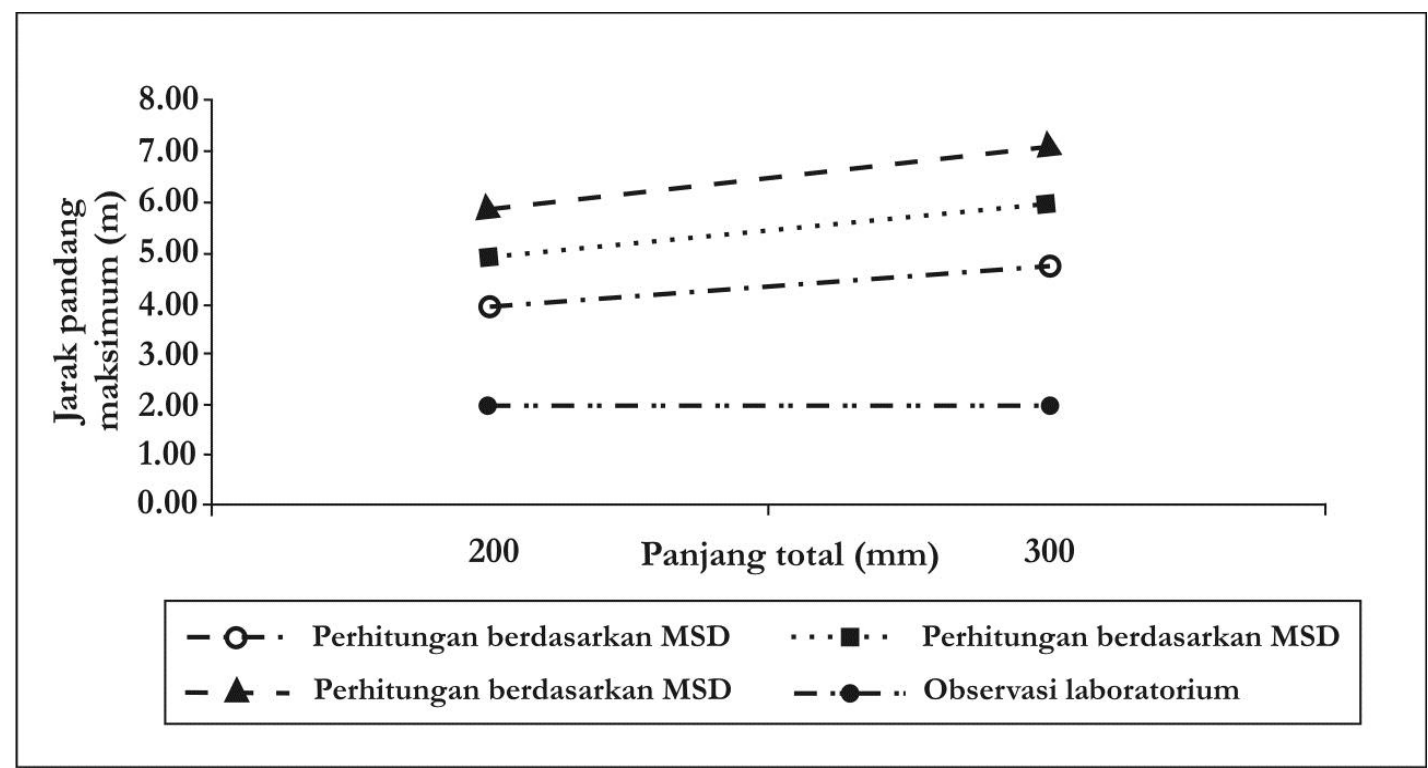

Gambar 12 Jarak pandang maksimum dan jarak ikan kerapu macan merespons umpan di laboratorium.

Terdapat kecenderungan pertambahan panjang total meningkatkan angka jarak pandang mak-simum (MSD). Menurut Zhang dan Arimoto (1993), dan He 1989 bahwa kemampuan jarak pandang maksimum ikan akan berbeda seiring dengan perbedaan ukuran panjang tubuhnya. Penambahan ukuran panjang ikan menyebabkan peningkatan jarak pandang ikan.

\section{KESIMPULAN}

Berdasarkan hasil penelitian ini dapat disimpulkan bahwa (1) morfologi retina mata ikan kerapu macan terdiri dari sel kon tunggal (sing- le cone) dan sel kon ganda (double cone) yang membentuk susunan mozaik (satu sel kon tunggal di kelilingi empat buah sel kon ganda), sumbu penglihatan ke arah depan naik (upper-fore) dengan sudut $26,8^{\circ}$, ketajaman penglihatan ikan kerapu macan tergolong rendah dengan nilai indeks penglihatan (visual acuity) berkisar 0,06-0,07 untuk ikan dengan panjang total 200$300 \mathrm{~mm}$, jarak pandang maksimum untuk umpan dengan diameter $20 \mathrm{~mm}$ berkisar 3,93-4,74 $\mathrm{m}$, umpan dengan ukuran diameter $25 \mathrm{~mm}$ berkisar 4,91-5,92, dan umpan dengan diameter $30 \mathrm{~mm}$ berkisar 5,89-7,11 m. (2) Frekuensi ikan menghampiri umpan dengan ukuran $30 \mathrm{~cm}$ sebesar $45,83 \%$, ukuran $25 \mathrm{~cm}$ sebesar $33,33 \%$ dan umpan berukuran $20 \mathrm{~cm}$ sebesar $20,83 \%$. 


\section{UCAPAN TERIMA KASIH}

Ucapan terima kasih disampaikan kepada Kementerian Riset dan Teknologi yang telah membiayai penelitian ini, LPPM IPB yang telah memfasilitasi bagi terlaksananya penelitian ini dan seluruh pihak yang telah memberikan bantuannya. Ucapan terima kasih juga penulis sampaikan kepada Dr. Aristi Dian PF, Deka B Sejati, S.Pi, dan Angga Nugraha, S.Pi yang telah membantu dalam melakukan pengumpulan data.

\section{DAFTAR PUSTAKA}

Agustini W. 2005. Ketajaman Penglihatan Ikan Gulamah (Argyrosomus amoyensis) Kaitannya Dengan Respons Penglihatan Terhadap Objek Jaring Arad [Skripsi]. Bogor: Departemen Pemanfaatan Sumber Daya Perikanan. Fakultas Perikanan dan IImu Kelautan. Institut Pertanian Bogor. $52 \mathrm{hlm}$.

Blaxter J.H.S. 1980. Vision and Feeding of Fish-es. In: Fish Behavior and Its Use in Cap-ture and Culture of Fish. ICLARM Conf. Proc (5): 32-56.

Geonita G. 2004. Ketajaman Penglihatan Kakap Merah Dalam Kaitannya Dengan Proses Penangkapan Menggunakan Pancing Ulur [Skripsi]. Bogor: Departemen Pemanfaatan Sumber Daya Perikanan. Fakultas Perikanan dan IImu Kelautan. Institut Pertanian Bogor. $41 \mathrm{hlm}$.

Gufran M.H. dan Kordi K. 2005. Budidaya Ikan Laut di Keramba Jaring Apung. Rineka Cipta, Jakarta.

He P. 1989. Fish Behaviour and Its Aplication in Fisheries. Newfoundland and Labrador Institut of Fisheries and Marine Technology, Canada. p 157.

Moye P.B. dan Cech J.J.C. 1988. Fisheries an Introduction to Ichthyology. $2^{\text {nd }}$ ed.
Prentize Hall, Engle Wood Cliffs, New Jersey.

Purbayanto A., S. Akiyama, \& T. Arimoto. 2001. Visual and Swimming Physiology of Japanese Whiting in Relation to The Capture Process of Sweeping Trammel Net. Proceeding of the $4^{\text {th }}$ JSPS International Seminar on Fisheries Science in Tropical Area (O. Carman et al., Eds) Tokyo University of Fisheries, Tokyo, International JSPS Project. Vol $10: 151$ 155.

Sale P.F. 1991. The Ecology of Fishes on Coral Reefs. Academic Press, Inc.. San Diego. New York. Boston. London. Sydney. Tokyo, Toronto.

Saparudin. 2005. Alternatif Solusi Budidaya Kerapu di Kabupaten Natuna. http://lc.bppt.go.id/iptek/index.php. 18 Maret 2008. 09. 08 WIB.

Shiobara Y., Akiyama S., \& Arimoto T. 1998. Developmental Changes in The Visual Acuity of Red Seam Beam (Pagus major). Journal Fisheries Science and Technology, Tokyo Uneversity of Fisheries. Tokyo. Jepang. $p$ : $944-947$.

Tampubolon G.H. dan Mulyadi E. 1989. Synopsis Ikan Kerapu di Perairan Indonesia. Balitbangkan, Semarang.

Tamura T. 1957. A Study of Visual Perception in Fish, Especially on Resolving Power and Accomodation. Bulletin of Japanese Society of Scientific Fisheries. Vol 22, No. 9. Fisheries Institute, Faculty of Agriculture, Japan. $p: 536-557$.

Zhang X.M. and Arimoto T. 1993. Visual Physiology of Walleye Pollock (Theragra chalcogramma) in Relation to Capture by Trawl Nets. ICES Marine Science Symposium. 196 : 113-116. 